\title{
Kemampuan pemecahan masalah siswa dalam menyelesaikan soal tertutup dan terbuka pada pokok bahasan lingkaran
}

\author{
Mela Aziza ${ }^{{ }^{*}}$ \\ ${ }^{1}$ Program Studi Tadris Matematika, IAIN Bengkulu, Indonesia \\ * Corresponding Author. E-mail: mela.aziza@iainbengkulu.ac.id
}

\begin{tabular}{ll}
\hline \multicolumn{1}{c}{ ARTICLE INFO } & \multicolumn{1}{c}{ ABSTRACT } \\
\hline Article History: & Penelitian ini adalah penelitian kualitatif deskriptif yang bertujuan untuk mendeskripsikan \\
Received: 8 August 2019 & kemampuan pemecahan masalah siswa kelas XI SMA dalam menyelesaikan soal-soal peme- \\
Revised: 16 Sept. 2019 & cahan masalah matematika pada pokok bahasan lingkaran. Subjek dalam penelitian ini adalah \\
Accepted: 27 Dec. 2019 & $\begin{array}{l}\text { 30 siswa di salah satu kelas XI IPA di SMA Negeri } 5 \text { Kota Bengkulu yang dipilih secara purposive } \\
\text { sampling. Setelah siswa mengerjakan 5 soal pemecahan masalah tentang lingkaran selama } 60\end{array}$ \\
& menit secara tertulis, jawaban siswa kemudian dianalisis dan diidentifikasi untuk menemukan \\
Keywords: & bagaimana siswa menyelesaikan soal, banyak strategi pemecahan masalah yang digunakan \\
Pemecahan masalah, & siswa, serta banyak solusi atau jawaban yang didapat. Hasil penelitian menunjukkan bahwa \\
Soal tertutup, & beberapa siswa belum mampu menyelesaikan masalah dengan tepat disebabkan kesalahan \\
Soal terbuka, & dalam langkah mensintesis dan menganalisis soal. Strategi yang mayoritas digunakan oleh para \\
Problem-solving, & siswa dalam menyelesaikan masalah adalah drawing a picture (menggambar). Siswa juga \\
Closed question, & menggunakan strategi guessing and checking (menebak dan menguji). Berkaitan dengan \\
Open-ended question. & banyaknya jawaban siswa, siswa menjawab soal tertutup dengan jawaban yang sama, sedang- \\
& kan untuk soal terbuka ditemukan tiga jawaban berbeda.
\end{tabular}

This research was descriptive qualitative research that aimed to describe the problem-solving abilities of eleventh-grade students in solving mathematical problems on the subject of the circle. The subjects in this study were 30 students in one of the XI Science classes in SMA Negeri 5 Bengkulu City, Indonesia selected by purposive sampling. After students worked on five problem-solving questions about the circle for 60 minutes in writing-form, the students' answers were then analyzed and identified to find how students solve the problems, how many problemsolving strategies used by students as well as many solutions or answers obtained. The research finding showed that some students have been not able to solve the problems correctly due to their misconceptions when doing the steps of synthesizing and analyzing. The majority of the strategies used by students in solving problems were drawing a picture. Students also used the guessing and checking strategy. Regarding the number of students' answers found, students answered closed questions with the same answers while for open-ended questions, it was found that students were able to find three different answers.

\section{SCAN ME}

This is an open access article under the CC-BY-SA license

\section{How to Cite:}

Aziza, M. (2019). Kemampuan pemecahan masalah siswa dalam menyelesaikan soal tertutup dan terbuka pada pokok bahasan lingkaran. PYTHAGORAS: Jurnal Pendidikan Matematika, 14(2), 126-138. doi: https://doi.org/10.21831/pg.v14i2.26563

https://doi.org/10.21831/pg.v14i2.26563

\section{PENDAHULUAN}

Kemampuan pemecahan masalah adalah salah satu kemampuan yang diharapkan dapat dimiliki oleh siswa selama proses pembelajaran matematika. Kurikulum internasional matematika juga sudah sejak lama fokus pada pengembangan kemampuan pemecahan masalah pada setiap aktivitas belajar dan mengajar matematika (Anderson, 2009). Hal ini juga selaras dengan standar pada National Council of Teachers of Mathematics (NCTM) yang menekankan pada kemampuan pemecahan masalah sejak tahun 1989 untuk kurikulum sekolah matematika (NCTM, 1989; 2000). Anderson (2009) juga menemukan bahwa beberapa negara sudah menjadikan kemampuan pemecahan masalah sebagai salah satu tujuan penting dalam kurikulum matematika mereka seperti Singapura, Hongkong, Inggris, dan Belanda. 
Namun sayangnya, pemecahan masalah masih dianggap sebagai aktivitas yang kompleks (Nunokawa, 2005). Kemampuan pemecahan masalah adalah salah satu kelemahan yang masih dihadapi oleh para siswa selama belajar matematika (Tambychik \& Meerah, 2010; Wood, 2005, p.75;) termasuk siswa-siswi di Indonesia. Fakta ini terlihat dari peringkat yang diperoleh oleh Indonesia dalam data survei TIMSS 2015, dimana Indonesia hanya memperoleh peringkat ke-45 dari 50 (Mullis, Martin, Foy, \& Hooper, 2015, p.20). Rendahnya prestasi siswa Indonesia dalam pemecahan masalah juga terlihat pada data PISA 2015, Indonesia hanya menduduki peringkat 69 dari 76 (OECD, 2016), dimana ini merupakan posisi 10 terbawah.

Salah satu upaya untuk meningkatkan kemampuan pemecahan masalah siswa adalah dengan melatihkan soal-soal pemecahan masalah. Melalui pemberian soal-soal, Martino dan Maher (1994), Boaler dan Brodie (2004) mengatakan bahwa seorang guru bisa menciptakan keaktifan kelas (rich classroom). Hal ini disebabkan ketika siswa setelah selesai menjawab soal, biasanya guru akan melakukan diskusi bersama untuk membahas jawaban soal. Selain itu, dengan menyelesaikan soal-soal pemecahan masalah, siswa dimungkinkan memperoleh pengalaman menggunakan pengetahuan serta keterampilan yang sudah dimiliki untuk diterapkan dalam proses pemecahan soal yang dinyatakan sebagai masalah (Tofade, Elsner, \& Haines, 2013; Hufferd-Ackles, Fuson, \& Sherin, 2004; Owen \& Milner, 1998).

Dalam proses untuk mengembangkan kemampuan pemecahan masalah siswa, Anderson (2009) berpendapat bahwa para guru sebaiknya fokus pada soal-soal matematika yang bukan sekedar soal biasa (rutin), tetapi juga soal-soal pada skala masalah matematika (non-rutin). Hal ini karena selama menyelesaikan soal-soal yang termasuk soal pemecah masalah, siswa akan membutuhkan kemampuan pemahaman matematika, pengetahuan dan konsep matematika, bernalar secara matematis, dan berkomunikasi (Anderson, 2009; Chan, 2007).

Faktanya, ketika peneliti melakukan observasi langsung ke sekolah, selama proses pembelajaran matematika kebanyakan guru masih sangat jarang memberikan soal-soal pemecahan masalah pada siswa. Hal ini disebabkan guru masih bergantung pada soal-soal dari buku ajar, padahal buku ajar matematika yang ada saat ini kurang memuat soal-soal pemecahan masalah (non-rutin) dan banyak memuat soal biasa (rutin) yang prosedural penyelesaiannya bisa dikatakan standar (Mulyati, 2016). Temuan ini mengindikasikan bahwa pembelajaran di sekolah tersebut belum menyentuh pada pengembangan kemampuan pemecahan masalah lewat pemberian soal-soal yang terkategori sebagai soal pemecahan masalah. Keadaan inilah membuat siswa belum mempunyai kesempatan untuk mengasah kemampuan pemecahan masalah mereka.

Hibert (Van de Walle, 2006, p.38) mengatakan bahwa membuat materi pelajaran menjadi problematis berarti membuat siswa untuk ingin tahu mengapa sesuatu demikian, menyelidiki soal, mencari solusi dan menyelesaikan keganjilan-keganjilan yang ada. Hal ini berarti bahwa kurikulum dalam pengajaran harus dimulai dengan soal-soal, dilema-dilema, dan pernyataan-pernyataan untuk siswa. Tetapi tidak semua soal bisa dikatakan sebagai masalah, karena jika untuk memecahkan soal tersebut siswa hanya menggunakan prosedur biasa maka soal tersebut tidak bisa disebut sebagai masalah matematika. Rasiman (2012) mengatakan bahwa soal matematika disebut bukan masalah matematika apabila siswa dapat segera mengetahui metode/prosedur untuk menjawab soal itu atau siswa tidak berkeinginan untuk menyelesaikan soal tersebut. Selaras dengan pendapat Rasiman, Cooney, Harvis, dan Henderson (Shadiq, 2004) menyatakan bahwa suatu pertanyaan akan menjadi masalah hanya jika pertanyaan itu menunjukkan adanya suatu tantangan yang tidak dapat dipecahkan oleh suatu prosedur rutin yang sudah diketahui si pelaku. Untuk memecahkan atau menyelesaikan suatu masalah matematika siswa perlu melakukan kegiatan mental (berpikir) yang lebih banyak dan kompleks dari pada kegiatan mental yang ia lakukan saat menyelesaikan soal yang bukan masalah matematika. Oleh karena itu, soal pemecahan masalah merupakan soalsoal yang sifatnya non rutin.

Suandito, Darmawijoyo, dan Purwoko (2009) menyebutkan bahwa kriteria soal non rutin yaitu mampu mengeluarkan banyak ide, mampu menggunakan strategi penyelesaian tunggal (tertutup) dan tidak tunggal (terbuka), mampu menggunakan gabungan beberapa cara penyelesaian, mampu menguraikan secara terperinci, dan mencetuskan gagasan unik pada saat penyelesaian soal. Kwon, Park, dan Park (2006), Yee (2002), Nohda (2000), dan Pehkonen (1999) lebih jauh merincikan dua jenis soal berdasarkan kemungkinan jumlah jawaban yang muncul dari sebuah soal, yaitu closed questions (satu jawaban) dan open-ended questions (lebih dari satu jawaban). Kaitannya dengan soal pemecahan masalah sebagai soal yang tidak otomatis diketahui cara penyelesaiannya (non rutin), maka soal tersebut bisa berupa soal tertutup atau soal terbuka, serta soal tersebut menuntut kemampuan analisis dan sintesis siswa dalam menyelesaikannya. 
Kemampuan pemecahan masalah pada dasarnya melibatkan proses belajar untuk menggunakan metodemetode ilmiah atau berpikir secara sistematis, logis, teratur, dan teliti. Oleh karena itu, kemampuan siswa dalam menguasai konsep-konsep, prinsip-prinsip, dan generalisasi sangat diperlukan terutama dalam langkah-langkah pemecahan masalah. Jhon Dewey (Ahmadi dan Prasetya, 2005) telah menganalisis langkah-langkah yang harus dicapai dalam memecahkan masalah, yaitu: menyadari adanya masalah (dengan menimbulkan tanda tanya dalam pikiran); memahami hakikat masalah dengan jelas (kejelasan rumusan masalah); mengajukan hipotesis (dugaan jawaban); mengumpulkan data (membuktikan benar tidaknya hipotesis); analisis dan sintesis data (data yang dikumpulkan harus ditinjau dan dianalisa kebenarannya secara kritis); mengambil kesimpulan; mencoba dan menerapkan kesimpulan (memeriksa kembali kesimpulan); serta mengevaluasi seluruh proses pemecahan masalah

Dalam memecahkan masalah, diperlukan beberapa strategi untuk mempermudah siswa ketika melakukan langkah analisis dan sintesis data dalam menemukan solusi yang tepat. Sonnabend (2010, p.54) menyebutkan beberapa strategi pemecahan masalah yaitu: using inductive reasoning, using logical (deductive) reasoning, guessing and checking, systematic trial, inferential trial, making a table or list, drawing a picture, solving a simpler problem, working backward, using a graph, and using an equation.

Using inductive reasoning (menggunakan penalaran induktif) adalah proses penalaran dalam memperoleh kesimpulan umum yang didasarkan pada data empiris. Penalaran induktif biasa disebut induksi (proses penalaran dari khusus ke umum). Using logical (deductive) reasoning (menggunakan penalaran deduktif/berpikir logis) adalah proses penalaran yang kesimpulannya diturunkan secara mutlak menurut premis-premisnya. Penalaran induktif biasa disebut deduksi (proses penalaran dari umum ke khusus). Biasanya dalil atau teorema dalam geometri dibuktikan kebenarannya secara deduktif. Jika secara deduktif telah dapat dibuktikan kebenarannya, maka kebenaran itu berlaku secara umum.

Guessing and checking (menebak dan menguji) adalah strategi menebak dalam matematika memiliki landasan penalaran, bukan asal tebak. Strategi ini dapat dibedakan menjadi dua: sistematis dan inferensial. Systematic trial adalah menebak semua kemungkinan (ini baik bila memungkinkan atau bila kemungkinannya sedikit), sedangkan inferential trial adalah menebak dengan memilah-milah yang paling relevan berdasarkan konsep atau aturan tertentu. Hasil tebakan tentu saja harus diuji kebenarannya serta diikuti sejumlah alasan yang logis.

Making a table or list (membuat tabel atau daftar) adalah strategi yang membantu mempermudah siswa untuk melihat pola dan memperjelas informasi yang hilang. Dengan kata lain, strategi ini sangat membantu dalam mengklasifikasi dan menyusun informasi atau data dalam jumlah besar. Drawing a picture (menggambar) adalah strategi yang digunakan untuk menyederhanakan masalah dan memperjelas hubungan yang ada. Untuk membuat gambar atau diagram ini, kita tidak perlu membuatnya secara detail tetapi cukup yang berhubungan dengan permasalahan yang ada.

Solving a simpler problem (memecahkan masalah yang lebih sederhana) adalah strategi menyelesaikan masalah yang rumit dengan cara menyelesaikan masalah yang serupa tetapi lebih sederhana. Working backward (bekerja mundur) adalah strategi yang cocok untuk menjawab permasalahan yang menyajikan kondisi (hasil) akhir dan menanyakan sesuatu yang terjadi sebelumnya. Using a graph (menggunakan grafik) adalah strategi yang digunakan untuk menyederhanakan masalah dan memperjelas hubungan yang ada pada data dalam bentuk grafik. Terakhir adalah stategi Using an equation (menggunakan persamaan) yaitu strategi melihat apa yang diketahui dari soal dan kemudian menganalisis hubungannya untuk dibuat sebuah persamaan dalam menyelesaikannya.

Berdasarkan latar belakang masalah dan kajian literatur yang telah dikemukakan, dapat dipahami bahwa usaha untuk meningkatkan kemampuan pemecahan masalah siswa, khususnya dalam pembelajaran matematika, penting dilakukan. Usaha tersebut tentunya dapat diawali dengan kajian-kajian terkait kemampuan pemecahan masalah siswa saat ini. Untuk itu penelitian ini bertujuan untuk menganalisis kemampuan pemecahan masalah siswa dilihat dari bagaimana langkah siswa menyelesaikan setiap masalah/soal, banyaknya jawaban yang ditemukan, serta strategi pemecahan masalah yang digunakan selama menyelesaikan soal pemecahan masalah. 


\section{METODE}

\section{Subjek Penelitian}

Penelitian yang dilakukan adalah penelitian deskriptif kualitatif dengan subjek penelitian adalah siswa-siswi kelas XI IPA 1 SMA Negeri 5 Kota Bengkulu yang terdiri dari 30 siswa (rentang usia 16-17 tahun). Pemilihan sampel penelitian dilakukan dengan teknik purposive sampling dimana sampel dipilih sesuai dengan ciri-ciri khusus yang ditetapkan peneliti sehingga bisa menjawab pertanyaan penelitian (Sugiyono, 2007). SMA Negeri 5 Kota Bengkulu sudah terakreditasi A dan merupakan salah satu SMA favorit di kota Bengkulu. Berdasarkan hasil observasi di SMA Negeri 5 Kota Bengkulu, peneliti melihat secara langsung bagaimana keadaan pembelajaran di sekolah tersebut. Pada umumnya kemampuan siswa dalam memahami matematika sudah baik, tetapi kemampuan siswa dalam menerapkan pengetahuan dan keterampilan yang sudah ada untuk mengidentifikasi pertanyaan-pertanyaan yang memuat permasalahan masih kurang. Mereka juga masih kesulitan dalam merencanakan dan menentukan langkah-langkah yang dibutuhkan untuk memecahkan masalah tersebut. Hal ini disebabkan karena mereka masih terpaku pada contoh soal yang diberikan. Akibatnya, guru masih harus membantu dan membimbing mereka dalam menentukan strategi pemecahan masalah. Oleh karena itu, pemilihan SMA Negeri 5 sebagai sampel bisa membantu peneliti dalam menjawab permasalahan penelitian.

\section{Prosedur dan Instrumen Penelitian}

Adapun prosedur penelitian ini adalah diawali dengan membuat kisi-kisi soal-soal pemecahan masalah tentang lingkaran. Setelah itu, dibuat lima soal pemecahan masalah lingkaran yang sesuai dengan kisi-kisi tersebut. Kelima soal tersebut kemudian divalidasi oleh para ahli (validator). Validasi ahli yang dimaksud adalah proses memvalidasi soal yang dikembangkan pada tahap perancangan melalui pembuktian validitas secara rasional. Tahap validasi ini mencakup validasi materi berdasarkan isi (soal sesuai dengan kompetensi dasar dan indikator), konstruk (sesuai dengan teori dan kriteria soal problem solving), dan bahasa (sesuai dengan kaidah bahasa Indonesia yang berlaku dan EYD), serta validasi media meliputi jenis dan ukuran huruf, kejelasan cetakan, penomoran, kepadatan halaman, ruang dan tata letak, serta pemilihan warna. Proses validasi ini melibatkan validator yang berkompeten dan mengerti tentang penyusunan soal-soal problem solving pada pokok bahasan lingkaran. Selain itu, validator juga memberikan masukan atau saran untuk menyempurnakan soal yang telah disusun. Adapun validator soal yaitu tiga orang yaitu dua orang dosen pendidikan matematika dan satu orang guru matematika di SMA Negeri 5 Kota Bengkulu. Saran-saran dari validator akan digunakan untuk merevisi soal draf I sehingga menghasilkan draf II soal yang valid. Soal yang valid ini kemudian diberikan kepada 30 siswa kelas XI IPA 1 SMAN 5 Kota Bengkulu untuk diselesaikan selama 60 menit (1 jam). Kemudian, semua jawaban siswa dianalisis.

\section{Validitas Instrumen}

Instrumen penelitian yaitu tes problem solving yang dikembangkan divalidasi oleh ahli. Lembar validasi soal digunakan untuk mendapatkan data mengenai pendapat para ahli (validator) terhadap soal yang disusun pada draf I sehingga menjadi bahan acuan dalam merevisi soal dan menganalisis kevalidan soal. Lembar tersebut terdiri dari "Lembar Validasi Soal oleh Ahli Materi" terkait isi, konstruk, dan bahasa soal serta "Lembar Validasi Soal oleh Ahli Media" terkait format, isi, dan bahasa soal. Sedangkan lembar soal dan solusi digunakan untuk mendapatkan bagaimana langkah-langkah pemecahan masalah, strategi pemecahan masalah serta kemungkinan banyak jawaban dari siswa terhadap kelima soal.

Untuk menganalisis data validasi ahli akan digunakan analisis deskriptif dengan cara merevisi soal berdasarkan catatan validator. Pemberian nilai validitas instrumen menggunakan rumus sebagai berikut.

$$
V R=\frac{\sum_{i=1}^{n} R A_{i}}{n}
$$

dimana $V R$ merupakan rata-rata total skor validitas dari ahli, $R A_{i}$ merupakan rata-rata aspek ke- $i$, dan $n$ merupakan banyaknya aspek yang dinilai. Kemudian mencocokkan rata-rata total validitas $(V R)$ dengan kriteria kevalidan soal problem solving menurut Khabibah (Adibah, 2009), seperti disajikan pada Tabel 1.

Data hasil diskusi dengan para ahli materi menunjukkan bahwa draf soal-soal problem solving yang divalidasi masih memerlukan beberapa revisi (susunan kalimat soal, posisi gambar, kejelasan, serta bentuk gambar lingkaran yang masih belum tepat pada soal). Namun setelah dilakukan revisi, soal dinyatakan valid. Salah satu butir soal yang dinyatakan valid dapat dilihat pada Gambar 1. 
Tabel 1. Kriteria Pengkategorian Kevalidan Instrumen

\begin{tabular}{ll}
\hline Interval skor & Kategori kevalidan \\
\hline $4 \leq V R \leq 5$ & Sangat Valid \\
$3 \leq V R<4$ & Valid \\
$2 \leq V R<3$ & Kurang Valid \\
$1 \leq V R<2$ & Tidak Valid \\
\hline
\end{tabular}

Analisis kevalidan berdasarkan data pengisian instrumen oleh uji ahli media menunjukkan bahwa Draf I yang telah diperbaiki berdasarkan materi revisi dinilai dengan skor rata-rata 4 yaitu "Sangat Valid". Analisis kevalidan berdasarkan data pengisian instrumen oleh uji ahli materi menunjukkan bahwa Draf I yang telah diperbaiki berdasarkan materi revisi dinilai dengan skor rata-rata 4.42 yaitu "Sangat Valid". Hasil dari proses validasi ini menghasilkan Draf II soal-soal problem solving yang valid.

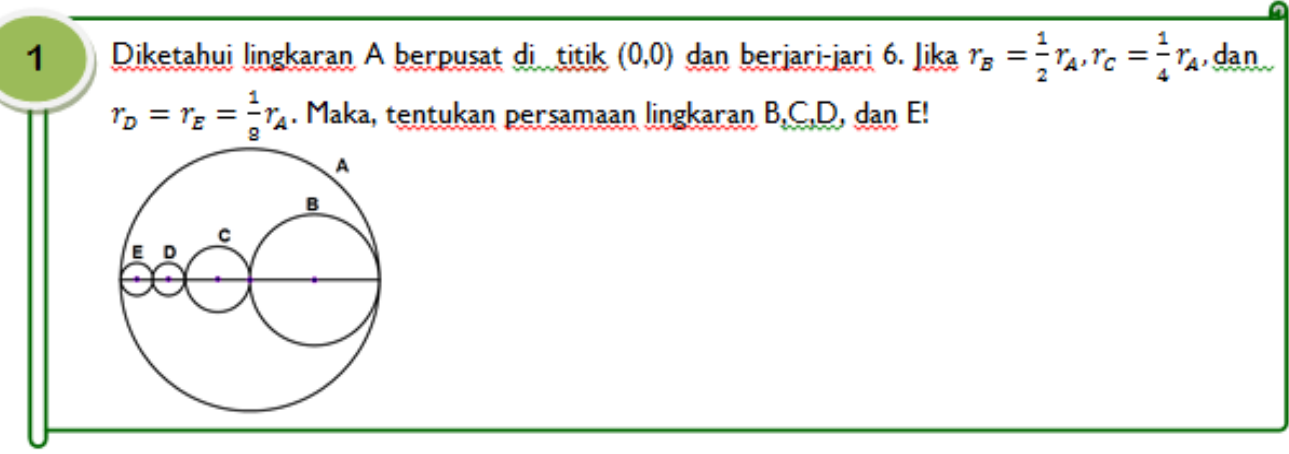

Gambar 1. Salah Satu Soal yang Dinyatakan Valid oleh Validator

\section{Teknik Analisis Data}

Jawaban siswa dianalisis menggunakan model Miles dan Hubermen (1984) yaitu dengan mereduksi data jawaban siswa, lalu menyajikan jawaban siswa dengan melihat langkah-langkah pemecahan masalah (berdasarkan 8 langkah pemecahan masalah dari Jhon Dewey (Ahmadi \& Prasetya, 2005), strategi yang digunakan siswa yaitu dengan melihat 10 strategi pemecahan masalah dari Sonnabend (2010, p.54), serta banyaknya jawaban yang ditemukan siswa (Kwon et al., 2006; Yee, 2002; Nohda, 2000; Pehkonen, 1999). Terakhir, dilakukan penarikan kesimpulan, sesuai dengan tujuan penelitian.

\section{HASIL DAN PEMBAHASAN}

\section{Langkah dan Strategi Pemecahkan Masalah Siswa}

Dari semua jawaban siswa ditemukan ada beberapa soal bisa dijawab dengan benar maupun tidak benar seperti terlihat pada Tabel 2.

Tabel 2. Rekapitulasi kebenaran jawaban siswa

\begin{tabular}{cll}
\hline No. & Jawaban Benar & Jawaban Kurang Benar \\
\hline 1 & $21(70 \%)$ & $9(30 \%)$ \\
2 & $11(36.7 \%)$ & $19(63.7 \%)$ \\
3 & $12(40 \%)$ & $18(60 \%)$ \\
4 & $6(20 \%)$ & $24(80 \%)$ \\
5 & $24(80 \%)$ & $6(20 \%)$ \\
\hline
\end{tabular}

Berdasarkan Tabel 2, terlihat bahwa dalam proses pemecahan masalah tidak semua siswa mampu menemukan jawaban yang benar. Hal ini disebabkan kesalahan dalam melakukan langkah pemecahan masalah terutama pada saat menganalisis dan mensintesis soal. Deskripsi kesalahan siswa saat memecahkan masalah diperoleh dari lembar solusi/jawaban siswa. Jhon Dewey (Ahmadi \& Prasetya, 2005) menjelaskan bahwa saat melakukan analisis dan sintesis data, problem solver harus meninjau data yang dikumpulkan dan kemudian menentukan apa yang harus dilakukan atau apa informasi tambahan yang dibutuhkan untuk memecahkan masalah tersebut. 
Pada soal nomor 1 (Gambar 2a), ada 21 siswa yang sudah bisa menganalisis dan mensintesis soal dengan tepat. Siswa sudah mampu mencari jari-jari dan titik pusat masing-masing lingkaran dengan menerapkan strategi berpikir logis dan menggunakan rumus persamaan lingkaran (Gambar 2b). Namun, masih ada 9 siswa yang melakukan kesalahan dalam menganalisis soal yaitu ketika menentukan koordinat titik pusat dan menyusun persamaan setiap lingkaran, siswa belum mampu menerapkan pengetahuan tentang jarak antara 2 titik dalam menentukan koordinat titik pusat yang bergeser di sumbu- $x$ (Gambar 2c dan Gambar 2d) sehingga koordinat titik pusat dan persamaan lingkaran yang diperoleh keliru.

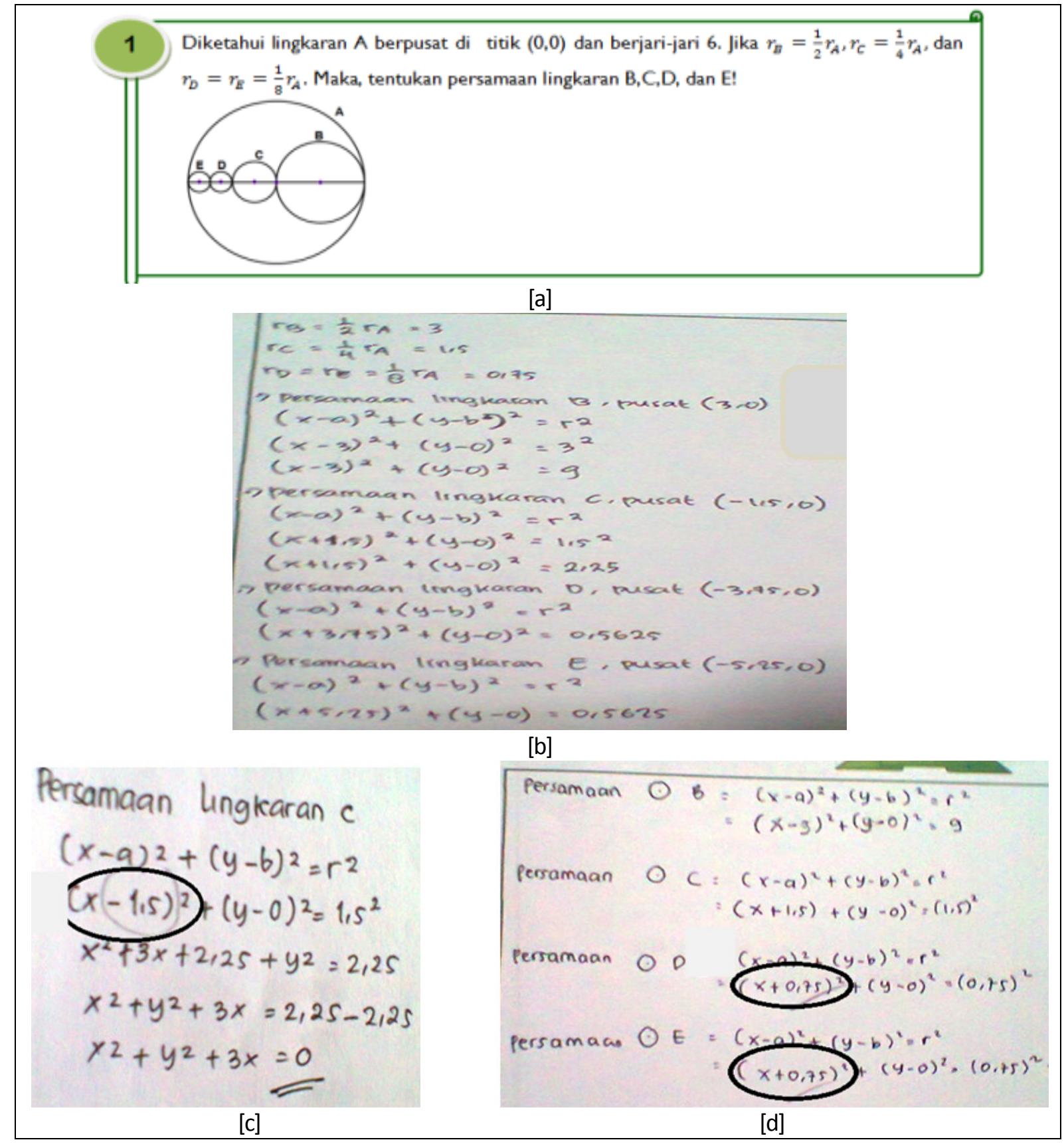

Gambar 2. Soal Nomor 1 dan Contoh Solusi Siswa

Pada soal nomor 2 (Gambar 3a), ada 11 siswa yang sudah bisa menganalisis dan mensintesis soal. Siswa sudah mampu mencari jari-jari lingkaran dan ordinat $y$ titik pusat lingkaran dengan menerapkan strategi menggambar (Gambar 3b) dan menggunakan rumus jarak antara dua titik (Gambar 3c). Namun, masih ada 19 siswa yang melakukan kesalahan dalam menganalisis yaitu ketika menentukan ordinat $y$ titik pusat lingkaran sehingga absis $x$ titik pusat yang diperoleh pun keliru (Gambar 3d), di sini terlihat bahwa siswa belum mampu menentukan 
koordinat titik tengah suatu garis. Tetapi ada juga siswa yang salah memahami maksud soal sehingga ia salah dalam menggambar lingkaran yang dimaksud.

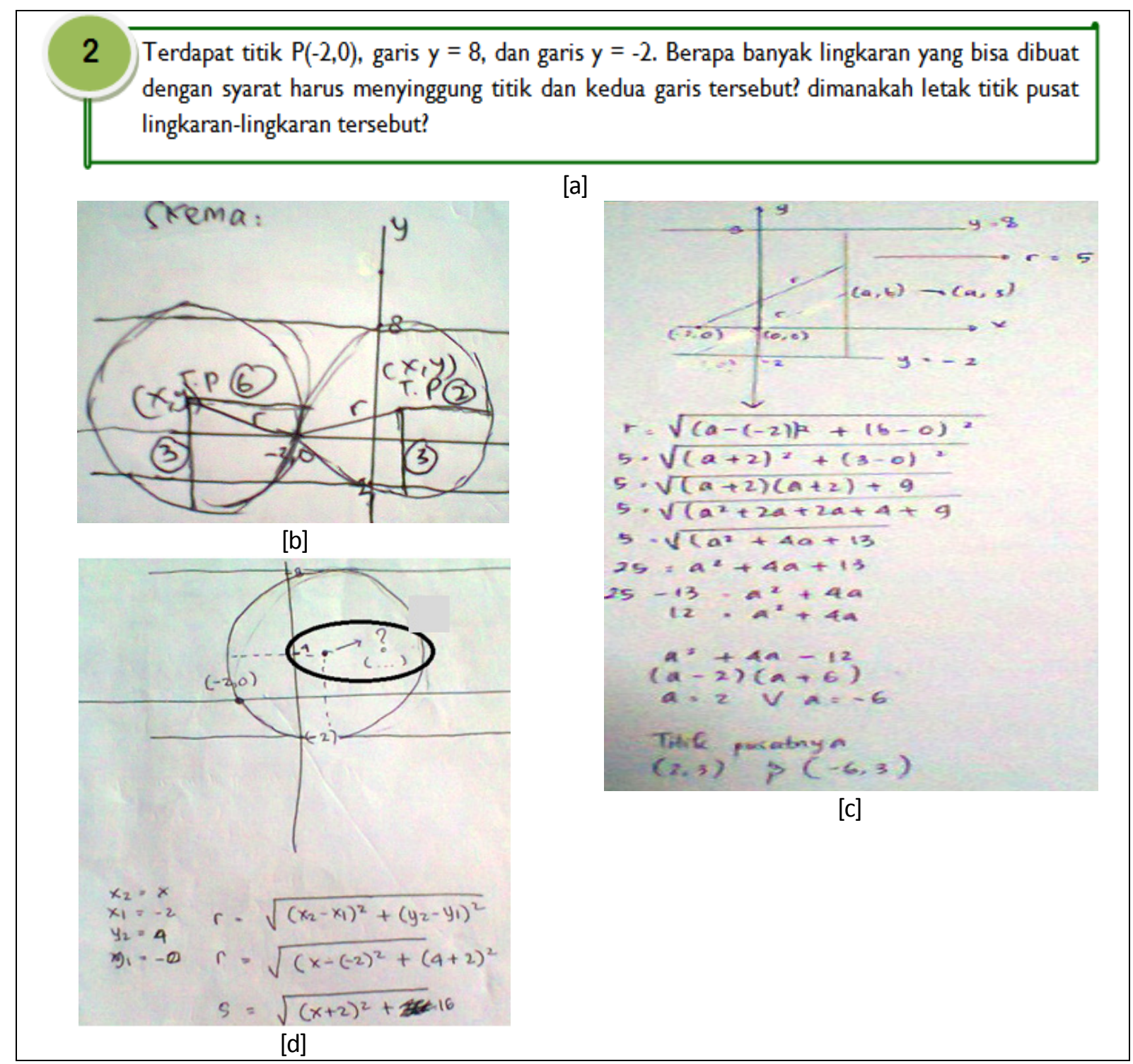

Gambar 3. Soal Nomor 2 dan Contoh Solusi Siswa

Pada soal nomor 3 (Gambar 4a), pada awalnya siswa mengalami kesulitan memahami maksud soal karena variabel koordinat titik yang digunakan adalah $x$ dan $y$. Dari rekapitulasi jawaban siswa, 12 siswa sudah bisa menganalisis dan mensintesis soal. Siswa sudah mampu mencari koordinat titik yang bergeser secara horizontal atau vertikal dengan menerapkan strategi berpikir logis (Gambar 4b) dan mencoba-coba atau menebak jawaban (Gambar 4c). Namun, masih ada 18 siswa yang melakukan kesalahan dalam menganalisis yaitu ketika menentukan koordinat titik B, C, dan D ketika ABCD adalah persegi, siswa berpikir bahwa koordinat B, C, dan D sama dengan ketika ABCD adalah persegi panjang (Gambar $4 \mathrm{~d}$ ). Mereka belum mampu mengaplikasikan sifat-sifat persegi dan persegi panjang dalam menentukan koordinat titik. 


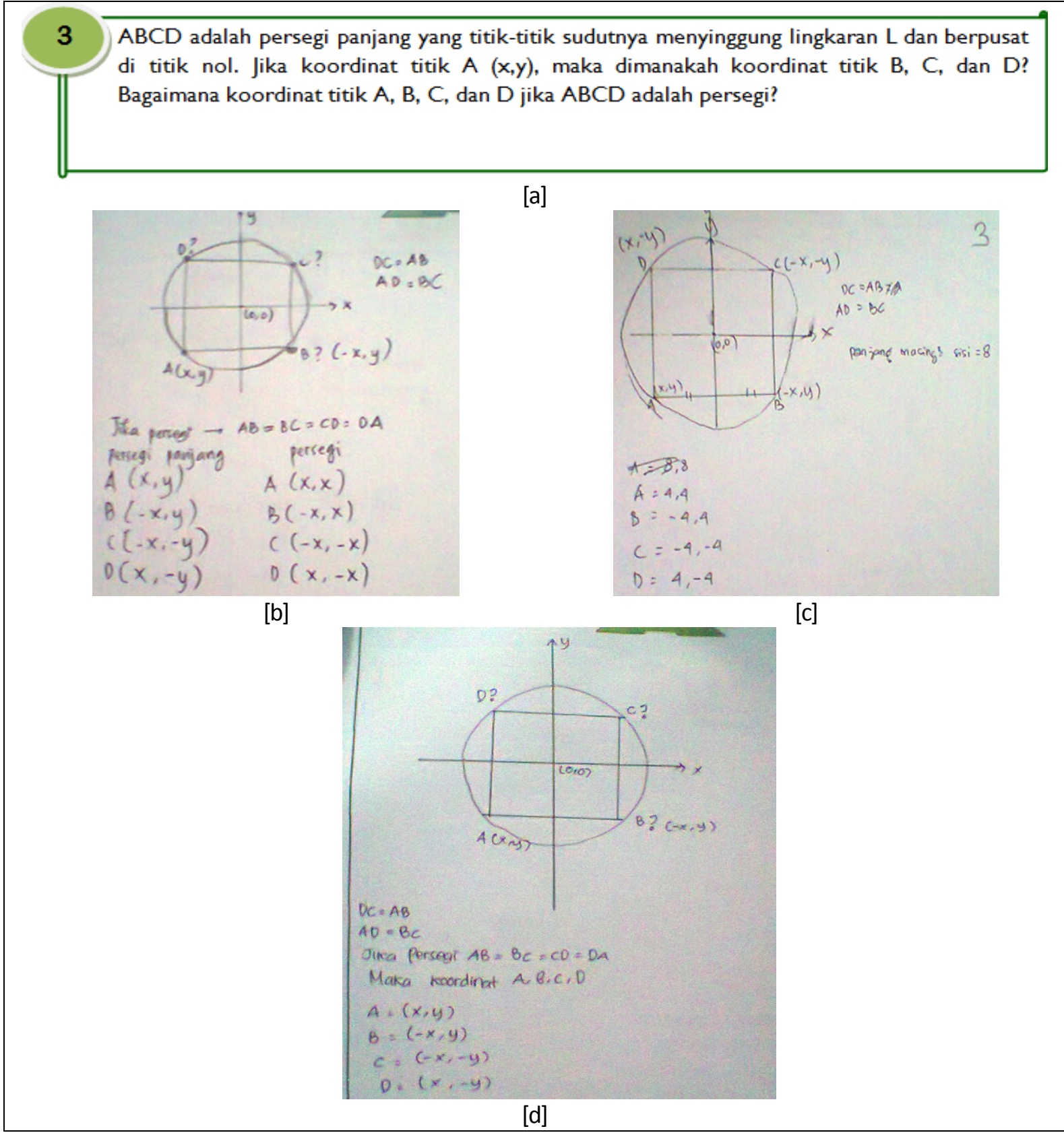

Gambar 4. Soal Nomor 3 Contoh Solusi Siswa

Pada soal nomor 4 (Gambar 5a), ada 6 siswa yang sudah bisa menganalisis dan mensintesis soal. Siswa sudah mampu mencari koordinat titik B dan $C$ agar terbentuk segitiga baik segitiga sama kaki maupun sama sisi dengan menerapkan strategi menggunakan persamaan Pythagoras (Gambar 5b) dan menggambar (Gambar 5c). Namun, masih ada 24 siswa yang melakukan kesalahan dalam menemukan solusi. Hal ini disebabkan siswa masih keliru dalam menerapkan pengetahuan tentang sifat-sifat segitiga sama kaki dan sama sisi (Gambar $5 d$ ). Siswa belum mampu mencari koordinat $B$ dan $C$ ketika $A B C$ adalah segitiga sama sisi. Siswa baru mampu menganalisis $A B=B C$ $=\mathrm{CA}$, namun tidak bisa menganalisis lebih lanjut dimana koordinat $\mathrm{B}$ dan $\mathrm{C}$. 


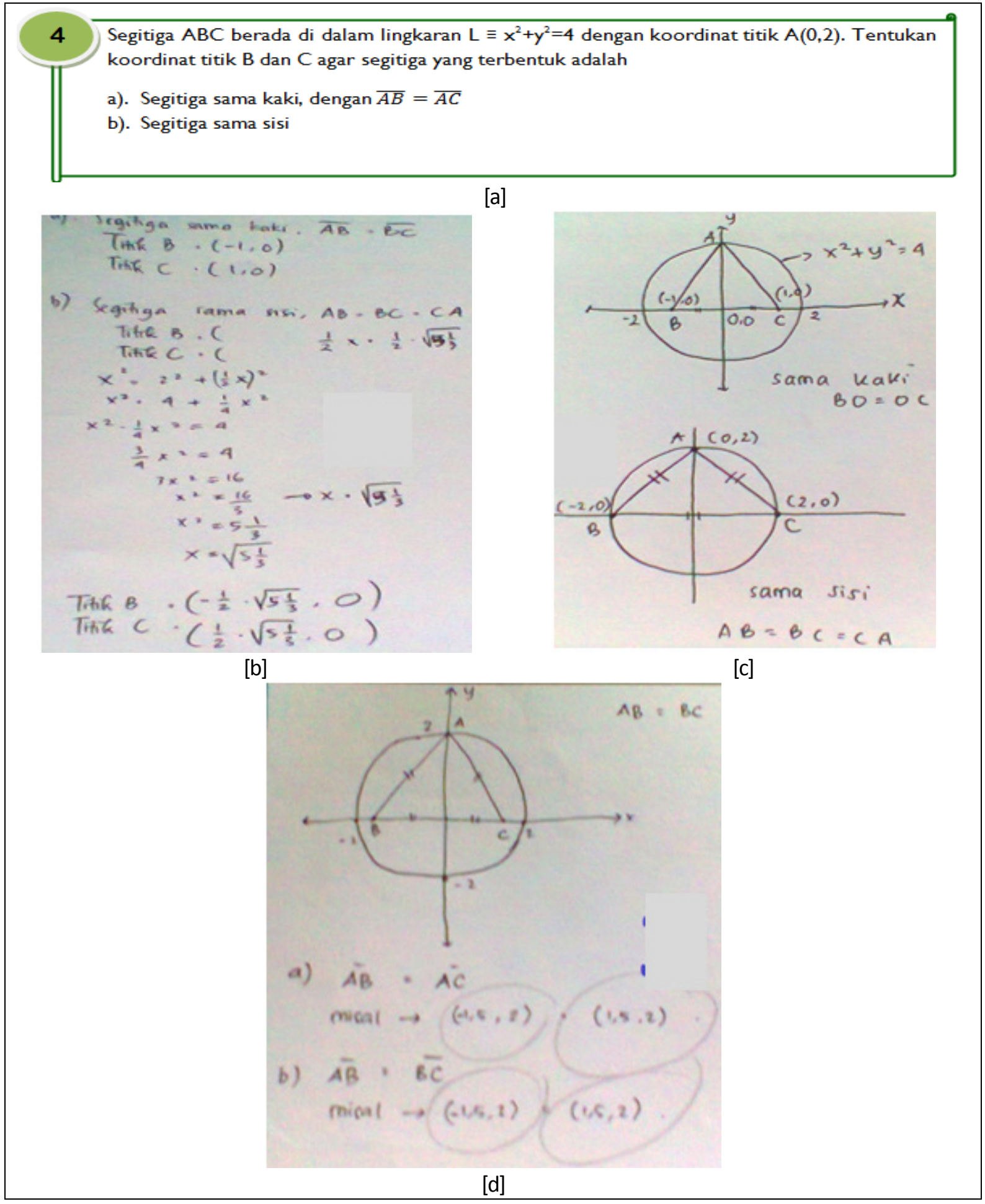

Gambar 5. Soal Nomor 4 dan Contoh Solusi Siswa

Pada soal nomor 5 (Gambar 6a), ada 24 siswa yang sudah mampu menganalisis dimana posisi titik P dengan strategi menggambar ketiga lingkaran (Gambar 6b). Namun, masih ada 6 siswa yang hanya sebatas mampu memahami masalah tetapi belum mampu melakukan pemecahan masalah yang tepat (Gambar $6 c$ dan Gambar 6d). 


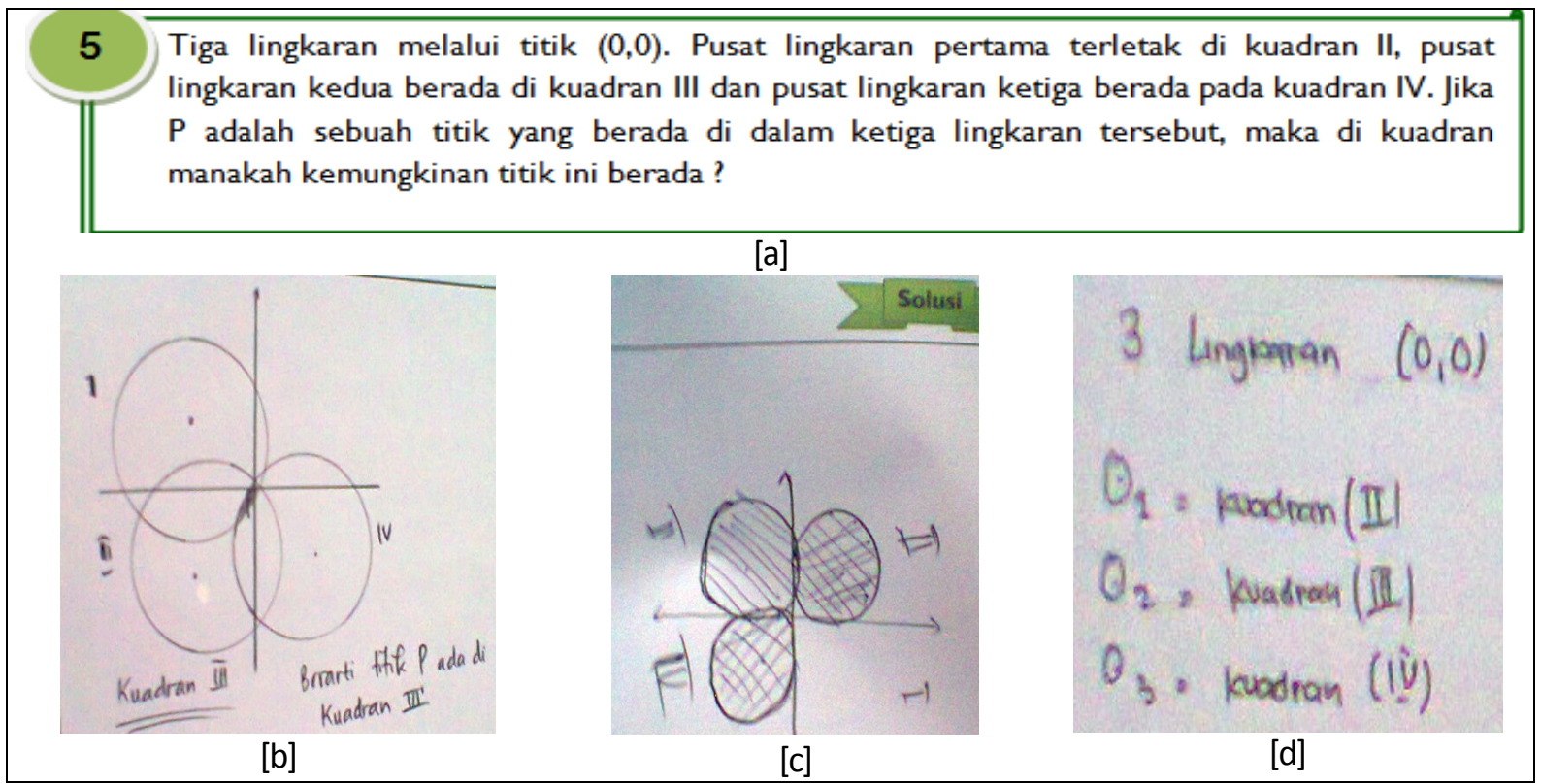

Gambar 6. Soal Nomor 5 dan Contoh Solusi Siswa

Setelah dilakukan analisis terhadap semua jawaban siswa, ditemukanlah bagaimana deskripsi kemampuan pemecahan masalah siswa berdasarkan banyaknya strategi (Sonnabend, 2010, p.54) yang digunakan. Terlihat bahwa strategi yang digunakan siswa dalam menjawab soal pemecahan masalah untuk soal nomor 5 hanya satu strategi yaitu menggambar (drawing). Ini memperlihatkan bahwa tidak banyak ide strategi yang muncul. Sedangkan untuk soal yang lain siswa sudah mampu menggunakan beberapa strategi (menggambar, menggunakan persamaan, menebak atau mencoba-coba, serta berpikir logis).

Strategi pemecahan masalah yang paling banyak digunakan siswa dalam memecahkan kelima soal problem solving ini adalah drawing a picture (menggambar) dan using an equation (menggunakan persamaan). Dari strategi pemecahan masalah yang banyak digunakan siswa, terlihat bahwa soal-soal problem solving tentang geometri banyak melibatkan keterampilan menggambar. Hal ini terkadang mengakibatkan strategi-strategi yang lain tidak banyak digunakan siswa. Khususnya saat siswa memecahkan soal nomor 5 , mereka tidak menggunakan rumus dan persamaan tetapi cukup dengan strategi menggambar saja.

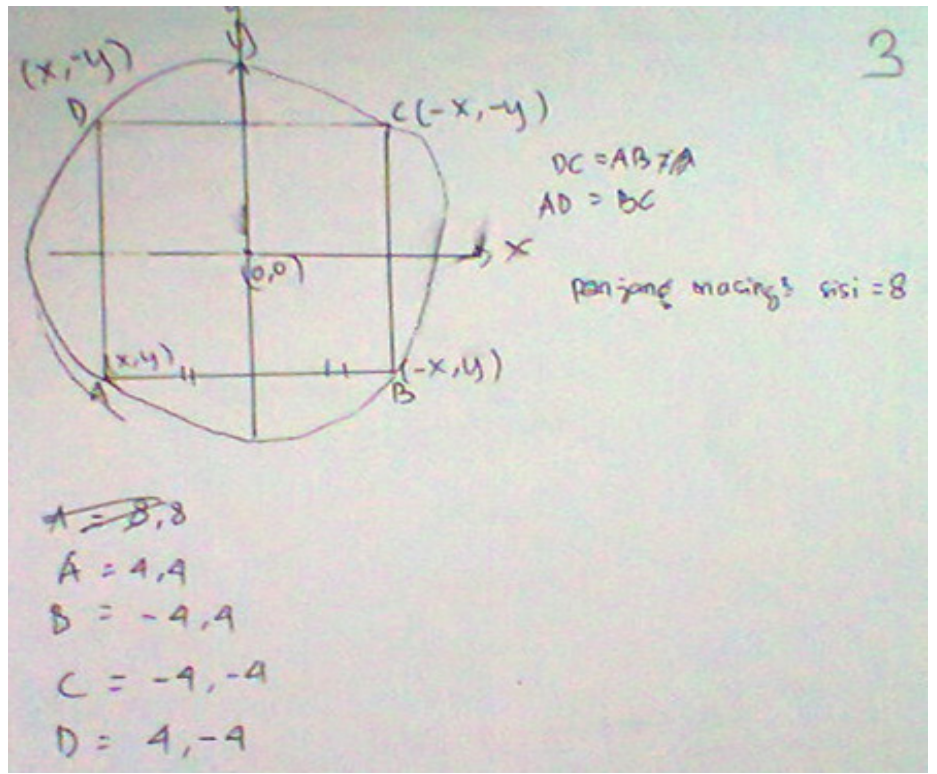

Gambar 7. Strategi Menebak untuk Soal Nomor 3

Strategi menebak (trial and error) juga digunakan beberapa siswa, tetapi hanya saat menjawab soal nomor 3 , yaitu ketika menentukan titik-titik koordinat sebuah persegi $A B C D$ (lihat Gambar 7). Dengan menggunakan strategi 
ini, siswa mampu menemukan jawaban yang benar. Dari deskripsi semua jawaban siswa terhadap lima soal pemecahan masalah pada pokok bahasan lingkaran, terlihat bahwa mayoritas siswa sudah mampu memahami masalah yang ada dalam setiap soal, memilih strategi pemecahan yang tepat, dan menerapkan pengetahuan yang telah mereka miliki dalam memecahkan masalah.

\section{Banyaknya Kemungkinan Jawaban yang Ditemukan Siswa}

Lima soal pemecahan masalah yang diberikan kepada 30 siswa XI IPA 1 terdiri dari empat soal tertutup (closed questions) yaitu soal nomor 1, 2, 3, dan 5 serta satu soal terbuka (open-ended question) yaitu nomor 4. Dari penelitian ini terlihat bahwa soal tetutup hanya mampu menstimulasi satu jawaban siswa, sedangkan soal terbuka mampu mendorong siswa untuk memberikan jawaban yang berbeda-beda. Seperti pada soal soal terbuka (openended questions) yaitu nomor 4, ditemukan adanya 3 solusi berbeda seperti terlihat pada Tabel 3.

Tabel 3. Solusi Siswa pada Soal Nomor 4

\begin{tabular}{ll}
\hline Solusi & $N$ \\
\hline $\mathrm{B}(-1,0)$ dan $\mathrm{C}(1,0)$ & 3 \\
$\mathrm{~B}(-2,0)$ dan $\mathrm{C}(2,0)$, & 2 \\
$\mathrm{~B}(-1.5,0)$ dan $\mathrm{C}(1.5,0)$, & 1 \\
\hline Keterangan: $N=$ Banyak siswa yang menjawab dengan Benar
\end{tabular}

Hal ini juga selaras dengan apa yang sudah ditemukan Aziza (2018) ketika meneliti tentang jawaban dan kreativitas matematika siswa ketika menjawab soal-soal yang diberikan guru di kelas. Aziza menemukan bahwa open-ended questions akan menstimulasi jawaban berbeda dari siswa.

Hal yang perlu dianalisis lebih mendalam adalah proses siswa dalam menemukan jawaban/solusi yang benar. Ketika menjawab sebuah masalah matematika, masih ada beberapa siswa yang melakukan kesalahan. Kesalahan tersebut berupa kesalahan dalam perhitungan, kesalahan dalam memahami konsep, dan kesalahan dalam ketepatan gambar secara geometri. Temuan terkait kesalahan dalam perhitungan dan kesalahan konsep sejalan dengan temuan penelitian Hadi, Retnawati, Munadi, Apino, dan Wulandari (2018); Pradini (2019); Setiawan, Hapizah, dan Hiltrimartin (2018). Namun, pada pemberian soal-soal pemecahan masalah ini bukan hanya sekedar fokus pada kebenaran solusi atau jawaban siswa, tetapi bagaimana selama proses pemecahan masalah siswa mampu memahami konsep matematika pada soal, kemudian bernalar secara matematis, dan berkomunikasi (Anderson, 2009; Chan, 2007).

\section{SIMPULAN}

Dari semua jawaban siswa pada setiap soal, terlihat bahwa mayoritas siswa sudah mampu memahami masalah yang ada dalam setiap soal, memilih strategi pemecahan yang tepat, dan menerapkan pengetahuan yang telah mereka miliki dalam memecahkan masalah. Strategi yang banyak digunakan siswa dalam memecahkan soalsoal pemecahan masalah ini adalah menggambar dan menggunakan persamaan atau rumus. Hal ini disebabkan soal-soal pemecahan masalah ini adalah soal-soal geometri yang banyak melibatkan keterampilan menggambar, sehingga kurang tepat jika menggunakan strategi-strategi yang lain. Beberapa siswa masih melakukan kesalahan yaitu kesalahan dalam perhitungan, kesalahan dalam memahami konsep, dan kesalahan dalam menggambar secara geometris. Jawaban yang menarik diperoleh dari soal nomor 5, dimana siswa memecahkan masalah tanpa menggunakan rumus dan persamaan tetapi cukup dengan menggambar saja.

Hal yang ditemukan selama penelitian ini belum bisa disimpulkan secara umum. Oleh karena itu, disarankan untuk melakukan penelitian dengan menggunakan sampel yang lebih luas dan soal pemecahan masalah yang lebih beragam. Soal pemecahan masalah yang diuji diharapkan tidak hanya menguji kemampuan pemecahan masalah siswa namun juga keberagaman jawaban yang ditemukan. Sehingga sangat dianjurkan memperbanyak soal-soal pemecahan masalah berbentuk soal terbuka (open-ended). Dengan memberikan berbagai soal pemecahan masalah, peneliti akan lebih banyak menemukan hal-hal yang bisa diuji lebih jauh lagi. Selain itu, dalam pembelajaran matematika, seorang guru mungkin bisa mulai membiasakan untuk mengembangkan soal-soal pemecahan masalah untuk semakin mengasa kemampuan siswa. 


\section{DAFTAR PUSTAKA}

Adibah, F.. (2009). Pengembangan Perangkat pembelajaran matematika dengan pendekatan inkuiri di kelas VIII MTs Negeri 2 Surabaya (Undergraduate thesis, UIN Sunan Ampel Surabaya, Surabaya). Retrieved from http://digilib.uinsby.ac.id/7908/

Ahmadi, A., \& Prasetya, J. T. (2005). Strategi belajar mengajar. Bandung: Pustaka Setia.

Anderson, J. (2009). Mathematics curriculum development and the role of problem solving. In Proceedings of 2009 Australian Curriculum Studies Association National Biennial Conference. Curriculum: A National Conversation (pp. 1-8). Retrieved from https://www.acsa.edu.au

Aziza, M. (2018). An analysis of a teacher's questioning related to students' responses and mathematical creativity in an elementary school in the UK. International Electronic Journal of Elementary Education, 10(4), 475-487. Retrieved from https://www.iejee.com/index.php/IEJEE/article/view/450

Boaler, J. \& Brodie, K. (2004). The importance, nature and impact of teacher questions. In D. E. McDougall, \& J. A. Ross (Eds.), Proceedings of the 26th Conference of the Psychology of Mathematics Education (North America, pp. 773-781). Toronto: OISE/UT.

Chan, C. M. E. (2007). Using open-ended mathematics problems: A classroom experience (Primary). In C. Shegar \& R. B. A. Rahim (Eds.), Redesigning pedagogy: Voices of Practitioners (pp. 129-146). Singapore: Pearson Education South Asia.

Hadi, S., Retnawati, H., Munadi, S., Apino, E., \& Wulandari, N. F. (2018). The difficulties of high school students in solving higher-order thinking skills problems. Problems of Education in the 21st Century, 76(4), 520-532. Retrieved from http://www.scientiasocialis.It/pec/node/files/pdf/vol76/520-532.Hadi_Vol.76-4_PEC.pdf

Hufferd-Ackles, K., Fuson, K. C., \& Sherin, M. G. (2004). Describing levels and components of a math-talk learning community.Journal for Research in Mathematics Education, 35(2), 81-116. doi: http://dx.doi.org/10.2307/30034933

Kwon, O. N., Park, J. H., \& Park, J. S. (2006). Cultivating divergent thinking in mathematics through an open-ended approach. Asia Pacific Education Review, 7(1), 51-61. doi: https://doi.org/10.1007/BF03036784

Martino, A. M., \& Maher, C. A. (1994). Teacher questioning to stimulate justification and generalization in mathematics. Paper presented at the Annual Meeting of te American Educational Research Association (New Orleans, LA, April 4-8, 1994). Retrieved from http://files.eric.ed.gov/fulltext/ED372945.pdf

Milles, M. B., \& Huberman, M. A. (1984). Qualitative Data Analysis. London, UK: Sage Publication.

Mullis, l., Martin, M., Foy, P., \& Hooper, M. (2015). TIMSS 2015 International Results in Mathematics. Boston, MA: TIMSS \& PIRLS International Study Centre. Retrieved from http://timss2015.org/download-center/

Mulyati, T. (2016). Kemampuan pemecahan masalah matematis siswa sekolah dasar. EDUHUMANIORA: Jurnal Pendidikan Dasar, 3(2). 1-15. doi: https://doi.org/10.17509/eh.v3i2.2807

NCTM. (1989). Curriculum and evaluation standards for school mathematics. Reston VA: Author.

NCTM. (2000). Principles and standards for school mathematics. Reston VA: Author.

Nohda, N. (2000). Teaching by open-approach method in Japanese mathematics classroom. Proceedings of the Conference of the International Group for the Psychology of Mathematics Education (PME) $\left(24^{\text {th }}\right.$, Hiroshima, Japan, July 23-27). Retrieved from http://files.eric.ed.gov/fulltext/ED466736.pdf

Nunokawa, K. (2005). Mathematical problem solving and learning mathematics: What we expect students to obtain. Journal of Mathematical Behavior, 24, 325-340. doi: https://doi.org/10.1016/j.jmathb.2005.09.002

OECD. (2016). PISA 2015: Results in focus. Paris: OECD Publishing. Retrieved from https://www.oecd.org/pisa/pisa2015-results-in-focus.pdf 
Owen Jr, W. E., \& Milner, J. O. (1998). The effects of teacher questioning patterns on classroom discourse. In L. McCoy (Ed.), Studies in teaching: Research Digest - Research Projects presented at Annual Research Forum (Winston-Salem, NC) (pp. 95-99).

Pehkonen, E. (1999). Open-ended problems: A method for an educational change. In International Symposium on Elementary Maths Teaching (SEMT 99), Charles University, Prague. Retrieved from http://szalonta.hu/mm/resources/task2/Pehkonen.pdf

Pradini, W. (2019). Analisis kesalahan siswa dalam menyelesaikan soal cerita persamaan linear dua variabel. PYTHAGORAS: Jurnal Pendidikan Matematika, 14(1), 33-45. doi: https://doi.org/10.21831/pg.v14i1.21481

Rasiman, R. (2012). Penulusuran proses berpikir kritis dalam menyelesaikan masalah matematika bagi siswa dengan kemampuan matematika tinggi. AKSIOMA: Jurnal Matematika dan Pendidikan Matematika, 3(1), 112. doi: http://dx.doi.org/10.26877/aks.v3i1/Maret.221

Setiawan, Y. B., Hapizah, H., \& Hiltrimartin, C. (2018). Kesalahan siswa dalam menyelesaikan soal olimpiade SMP konten aljabar. Jurnal Riset Pendidikan Matematika, 5(2), 233-243. doi: https://doi.org/10.21831/jrpm.v5i2.18191

Shadiq, F. (2004). Pemecahan masalah, penalaran, dan komunikasi (Online). Retrieved from https://asimtot.files.wordpress.com/2010/06/pemecahan-masalah-penalaran-dan-komunikasi.pdf

Sonnabend, T. (2010). Mathematics for teacher: An interactive approach for grades K-8 (4th ed.). Belmont, CA: Cengage Learning.

Suandito, B, Darmawijoyo, D., \& Purwoko, P. (2009). Pengembangan soal matematika non rutin di SMA Xaverius 4 Palembang. Jurnal Pendidikan Matematika, 3(2), 1-13. doi: https://doi.org/10.22342/jpm.3.2.325

Sugiyono, S. (2007). Statistika untuk penelitian. Bandung: Alfabeta

Tambychik, T., \& Meerah, T. S. M. (2010). Students' difficulties in mathematics problem-solving: What do they say? Procedia Social and Behavioral Sciences, 8, 142-151. doi: https://doi.org/10.1016/j.sbspro.2010.12.020

Tofade, T., Elsner, J., \& Haines, S. T. (2013). Best practice strategies for effective use of questions as a teaching tool. American Journal of Pharmaceutical Education, 77(7), 1-9. doi: https://doi.org/10.5688/ajpe777155

Van de Walle, J. A.(2006). Matematika sekolah dasar dan menengah: Pengembangan pengajaran matematika sekolah dasar dan menengah (S. Suryono, Trans.). Jakarta: Erlangga. (Original work publised 1892).

Wood, D. (2005). Kiat Mengerti Gangguan Belajar (I. Taniputera, Trans.). Yogyakarta: Kata Hati. (Orginial work published 2005).

Yee, F. Y. (2002). Using shortopen-ended mathematics questions to promote thinking and understanding. Singapore: NIE. Retrieved from http://math.unipa.it/ grim/SiFoong.PDF 